\title{
STANDAR ISI (KURIKULUM)
}

DOSEN PEMBIMBING:

Wahyu Bagja Sulfemi, M.pd

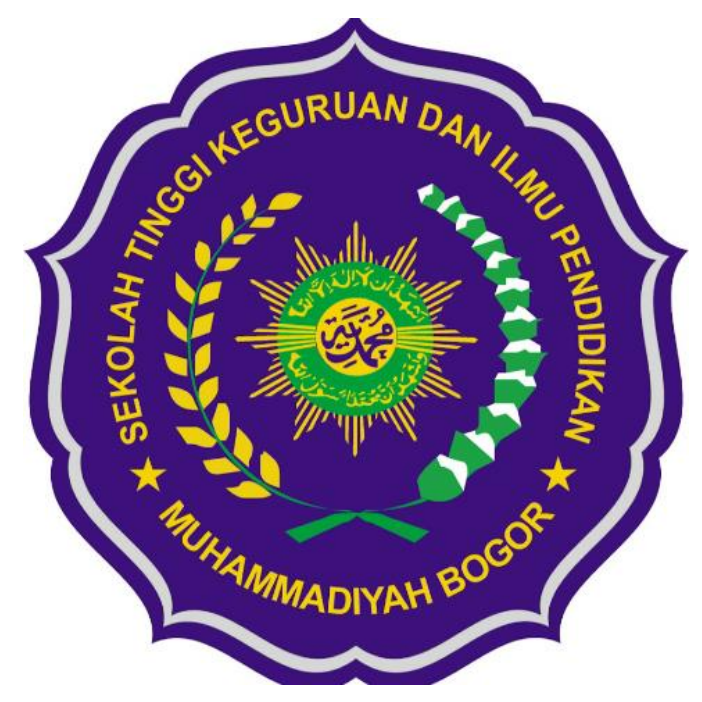

DISUSUN OLEH:

NENENG KHOIRUNNISA (0142S1A018028)

PROGRAM STUDI ADMINISTRASI PENDIDIKAN

STKIP MUHAMMADIYAH BOGOR 


\begin{abstract}
ABSTRAK
Kurikulum Sejatinya, kurikulum tidak hanya berisi serangkaian petunjuk teknis materi pembelajaran. Lebih dari itu, kurikulum merupakan sebuah program terencana dan menyeluruh, yang menggambarkan kualitas pendidikan suatu bangsa. Dengan sendirinya, kurikulum memegang peran srategis dalam kemajuan bangsa. Seiring dengan perkembangan zaman dan tuntutan kehidupan dalam masyarakat, kurikulum senantiasa berkembang dan menyelaraskan diri dengan kemajuan zaman. Melalui langkah-langkah yang sistematis, professional dan melibatkan seluruh aspek yang terkait dalam tercapainya tujuan penddidikan nasional.
\end{abstract}




\section{A. Pembahasan Materi}

\section{Pendidikan}

Pendidikan tidak pernah berlangsung dalam suatu ruangan hampa, melainkan selalu berlangsung didalam suatu masyarakat tertentu, dan untuk suatu tujuan kehidupan suatu masyarakat tertentu pula. Masyarakat dan kebudayaan merupakan dwi tunggal secara nyata dan tidak dapat dipisahkan. (Sulfemi, 2019)

Pendidikan merupakan sa;lah satu yang paling penting dalam pembentukan sumber daya manusia yang handal diberbagai bidang, seperti bidang ekonomi, teknologi, hukum, sosial budaya maupun bidang pertahanan keamanan. (Sulfemi, 2017:342)

a. Pengertian pendidikan

Pendidikan (education) secara semantik berasal dari bahasa yunani paidagogia yang berarti pergaulan dengan anak-anak. Pedagogos adalah seorang nelayan atau bujang dalam zaman yunani kuno yang pekerjaannya menjemput dan mengantar anakanak ke dan dari sekolah. Selain itu, di rumahnya anak tersebut selalu dalam pengawasan dan penjagaan para paedagogos. Istilah ini berasal dari kata paedos yang berarti anak, dan agogos yang berarti saya membimbing atau memimpin. (Sulfemi, 2018:1)

Dalam Undang-Undang No. 20 Tahun 2003 tentang sistem Pendidikan Nasional, yakni: pendidikan adalah usaha sadar dan terencana untuk mewujudkan suasana belajar dan proses pembelajaran agar peserta didik secara aktif mengembangkan potensi dirinya untuk memiliki kekuatan spiritual keagamaan, pengendalian diri, kepribadian, kecerdasan, akhlak mulia, serta keterampilan yang diperlukan dirinya, masyarakat, bangsa dan negara. (Sulfemi,2018: 2)

\section{Pengertian Standar isi, Kurikulum}

Standar isi mencakup lingkup materi minimal dan tingkat kompetensi minimal untuk mencapai kompetensi lulusan minimal pada jenjang dan jenis pendidikan tertentu.

Kurikulum merupakan seperangkat rencana dan program pendidikan yang digunakan sebagai acuan oleh lembaga penyelenggara pendidikan yang disesuaikan dengan jenjang dan kebutuhan peserta didik serta dengan memperhatikan budaya lokal.( Sulfemi, 2018: 3) 
Kebijaksanaan penerapan kurikulum tingkat satuan pendidikan (KTSP), keputusan dan peraturan pemerintah yang berhubungan dengan lembaga pendidikan atau jenjang/jenis sekolah yang bersangkutan. Dalam proses pendidikan perlu dilaksanakan manajemen kurikulum agar perencanaan, pelaksanaan, dan evaluasi kurikulum berjalan lebih efektif, efisien, dan optimal dalam memberdayakan berbagai sumber belajar, pengalaman belajar, maupun komponen kurikulum. (Sulfemi 2018: 4)

\section{Bentuk-bentuk kurikulum}

a. Subject matter/subject centered curriculum, yaitu kurikulum yang terdiri atas mata pelajaran yang terpisah-pisah. Materi yang dipelajari oleh siswa telah disusun secara logis oleh para ahli bidang studi. Contohnya : Sejarah, Biologi

b. Broad field/ fused/correlated curriculum, yaitu kurikulum yang disusun dengan mengkorelasikan atau menggabungkan sejumlah mata pelajaran dalam satu kesatuan dengan demikian terjadi perkawinan antar mata pelajaran sejenis. Contohnya: Ipa, Ips, Matematika, BahasaIndonesiadan Kesenian

c. Integreted Curriculum, yaitu kurikulum yang diorganisasikan dalam bentuk unitunit tanpa harus ada mata pelajaran atau bidang studi. Pembelajaran dilaksanakan dengan 'unit taching' dan materinya menggunakan 'unit lesson'. Pelajaran disusun bersama guru dan murid, mengandung suatu masalah yang luas, menggunakan metode 'problem solving', sesuai dengan minat dan perkembangan anak. Contohnya: Agama, Bahasa, Perhitungan

d. Core curriculum, yaitu kurikulum inti yang diberikan kepada semua murid untuk mencapai keseluruhan program kurikulum secara utuh. Contohnya: Agama, Ppkn

\section{Peranan dan Fungsi Kurikulum}

a. Peranan Kurikulum

Sebagai program pendidikan yang telah direncanakan secara sistematis, kurikulum mengemban peranan yang sangat penting bagi pendidikan siswa. Berikut tiga peranan kurikulum :

- Peranan konservatif

Salah satu tanggung jawab kurikulum adalah mentransmisikan dan menafsirkan warisan social pada generasi muda. Dengan adanya peranan ini sesungguhnya kurikulum itu berorientasi pada masa lampau. 
- Peranan kritis atau evaluatif

Dalam hal ini, kurikulum turut aktif berpartisipasi dalam control social dan memberi penekanan pada unsur berfikir kritis.

- Peranan kreatif

Kurikulum berperan dalam melakukan berbagai kegiatan kreatif dan konstruktif, dalam artian menciptakan dan menyusun suatau hal yang baru sesuai dengan kebutuhan masyarakat di masa sekarang dan masa mendatang.

b. Fungsi kurikulum

Disamping memiliki peranan, kurikulum juga mengemban berbagai fungsi tertentu. Alexander Inglis, dalam bukunya Principel of Secondary Education (1918), mengatakan bahwa fungsi kurikulum sebagai berikut:

- Fungsi penyesuain Individu hidup dalam lingkungan

- Fungsi integrasi

Kurikulum berfungsi mendidik pribadi-pribadi yang terintegrasi

- Fungsi diferensiasi

Kurikulum perlu memberikan pelayanan terhadap perbedaan di antara setiap orang dalam masyarakat

- Fungsi persiapan

Kurikulum berfungsi mempersiapkan siswa agar mampu melanjutkan studi lebih lanjut untuk suatu jangkauan yang lebih jauh

- Fungsi pemilihan

- Fungsi diagnostic

Kurikulum akan membimbing siswa untuk dapat berkembang secara optimal

Berbagai fungsi kurikulum di atas dilaksanakan oleh kurikulum secara keseluruhan. Fungsi-fungsi tersebut memberikan pengaruh terhadap pertumbuhan dan perkembangan siswa, sejalan dengan arah filsafat pendidikan dan tujuan pendidikan yang diharapkan oleh institusi pendidikan yang bersangkutan.

\section{Lapangan kurikulum}


Perencanaan dan pengembangan kurikulum harus didasarkan pada ide-ide umum tentang kurikulum, yang muncul berkat interaksi antara teori dan praktik. Adapun lapangan kurikulum yang memuat ide-ide tersebut berkenaan dengan proses konten pendidikan. Banyak ahli pendidikan melontarkan berbagai pemdapat yang berbeda mengenai kurikulum, perlu dirumuskan prinsip-prinsip dasar yang diperlukan jika hendak memperbaiki kurikulum.

- Bidang kurikulum adalah suatu area umum studi yang berkenaan dengan pengembangan dan implementasi tujuan (umum dan khusus) pendidikan dan alat untuk mencapainya, yang terdiri atas teori dan praktik terintegrasi

- Studi dan praktik dalam bidang kurikulum menuntut pemahaman yang luas tentang fondasi (filosofis, sosiologis, dan psikologis) kurikulum, yang mendasari tindakan kurikulum tersebut

- Pada praktiknya, bidang kurikulum meliputi perencanaan, pengembangan, desain instruksional, riset, perteorian, evaluasi dan kepemimpinan sebagai penunjang dan pendorong kurikulum

- Hasil pengamatan belajar dari kurikulum adalah terencana dan tersembunyi

- Segala keputusan yang berkaitan dengan bidang kurikulum harus melalui serangkaian proses yang kompleks dan memiliki banyak alternative

- Bidang kurikulum bersifat interdisiplin dan mengandung berbagai ide bersama dari bidang pendidikan lainnya, dalam perumusan tujuan maupun metode atau alat program-progran sekolah

- Semua kegiatan dalam bidang kurikulum harus mengacu pada hal tertentu, yang spesifik berkenaan dengan situasi belajar

\section{Berbagai masalah kurikulum}

Dalam proses pengembangan kurikulum, banyak sekali masalah yang dihadapi, yang memerlukan pertimbangan dan pemecahan tersendiri. Semua masalah tersebut disebabkan oleh berbagai kondisi yang ada, yang disesuaikan dengan tuntutan dan prinsip kebutuhan yang perlu dipenuhi.

a. Masalah umum 
- Bidang cakupan (Scope), sebagai 'luas' kurikulum, yang didalamnya mencakup berbagai topic, pengalaman belajar, aktivitas, pengorganisasian,'elemen-elemen', serta hubungan pengintegrasian dan pengorganisasian berbagai elemen tersebut

- Relevansi, merupakan masalah lain yang cukup esensial dan harus mendapatkan perhatian dalam pengembangan kurikulum

- Keseimbangan, kurikulum yang berpusat pada siswa

- Integrasi, memadukan, menggabungkan dan menyatukan antardisiplin ilmu

- Sekuens, berarti susunan atau urutan pengelompokan kegiatan atau langkahlangkah yang dilakukan dalam perencanaan kurikulum

- Kontinuitas, pengulangan terencana tentang isi untuk mencapai keberhasilan

- Artikulasi, sebagai pertautan antara kelompok elemen atau unsur lintas tingkatan sekolah

- Kemampuan transfer, prinsip dari pengajaran dan sekaligus juga prinsip dari kurikulum

b. Masalah khusus

- Berbagai masalah yang berhubungan dengan tujuan dan hasil-hasil kurikulum yang diharapkan oleh sekolah

- Berbagai masalah yang berhubungan dengan isi dan organisasi kurikulum

- Masalah yang berhubungan dengan proses penyusunan dan revisi kurikulum

\section{Peran guru dalam pengembangan kurikulum}

Dalam studi tentang ilmu mengajar dan kurikulum, pembahasan mengenai permasalahan yang dialami guru senantiasa mendapat tersendiri. Ini dikarenakan guru mengemban peran yang sangat penting dalam keberhasilan proses pendidikan. Bahkan berdasarkan pandangan yang ada sekarang ini, betapapun bagusnya kurikulum dan indahnya kurikulum, keberhasialan kurikulum tersebut pada akhirnya bergantung pada masing-masing guru.

Pada dasarnya, peran guru itulah yang paling mengetahui berbagai masalah kurikulum yang telah dilaksanakan. Oleh sebab itu berbagai saran mereka sangat diperlukan dalam perencanaan atau penyusunan kurikulum baru, tentu saja melalui prosedur langsung maupun tidak langsung. Melalui rapat sekolah, guru-guru dapat 
memberikan banyak bahan yang berharga dalam penyusunan kurikulum. Selanjutnya, secara bertingkatbahan-bahan tersebut disampaikan kepada suatupanitia khusus (panitia Pembina kurikulum) yang kemudian dijadikan bahan pembahasan dalam berbagai pertemuan penyusunan kurikulum.

Keberhasilan kurikulum sebagian besar terletak di tangan guru, selaku pelaksana kurikulum. Para guru bertanggung jawab sepenuhnya dalam pelaksanaan kurikulum, baik secara keseluruhan maupun sebagai tugas yang berupa penyam paian bidang studiatau mata pelajaran yang sesuai dengan program yang dirancang kurikulum.Sebagai pengelola kurikulum, guru bertanggung jawab lain membuat perencanaan mengajar, selain itu guru harus berusaha mengumpulkan dan mencari bahan dari berbagai sumber. Oleh karena itu dalam proses perubahan guru harus turut aktif dalam pengebangan kurikulum untuk memberikan berbagai input berupa saran dan pengalamannya.

\section{B. Simpulan}

Kurikulum adalah seperangkat rencana dan pengaturan mengenai tujuan, isi dan bahan pelajaran serta bahan yang digunakan sebagai pedoman penyelenggaraan kegiatan pembelajaran untuk mencapai tujuan pendidikan tertentu (Sulfemi : 3). Oleh karena itu, pengembangan kurikulum yang berupa proses dinamis dan integrative perlu diupayakan, melalui langkah-langkah yang sistematis, professional dan melibatkan seluruh aspek yang terkait dalam tercapainya tujuan pendidikan nasional. 


\section{Daftar Pustaka}

Hamalik,Oemar.2007.Dasar-Dasar PENGEMBANGAN KURIKULUM.

Bandung:PT Remaja Rosdakarya.

Sulfemi, Wahyu Bagja. (2018).Manajemen Kurikulum di Sekolah.Bogor:

Visi Nusantara Maju.

Sulfemi, Wahyu Bagja. (2017).Hubungan kurikulum 2013 dengan

Motivasi Belajar Peserta Didik di Smk Pelita Ciampea

Sulfemi, Wahyu Bagja. (2018).Modul Manajemen Pendidikan Non Formal.

Bogor: STKIP Muhammadiyah Bogor.

Sulfemi, wahyu Bagja. (2019).Manajemen Pendidikan Berbasis Multi Budaya.

Bogor: STKIP Muhammadiyah Bogor.

Sulfemi,Wahyu Bagja. (2017).Prosiding Seminar Nasional Pendidikan dan Kebudayaan STKIP Muhammadiyah Bogor.

https://id.wikipedia.org/wiki/Standar_Nasional_Pendidikan 


\section{Soal dan Jawaban}

\section{PILIHAN GANDA}

1. Sebutkan Bentuk-bentuk kurikulum?
a. Bulat
b. Transparan
c. Core Curriculum
d. Oval

2. seperangkat rencana dan program pendidikan yang digunakan sebagai acuan oleh lembaga penyelenggara pendidikan yang disesuaikan dengan jenjang dan kebutuhan peserta didik serta dengan memperhatikan budaya lokal, pengertian dari....?
a. Kurikulum
b. Pendidikan
c. Supervisi
d. Pembiayaan

3. Berikut adalah peranan kurikulum.... kecuali
a. Peranan Konservatif
b. Peranan Sempit
c. Peranan Luas
d. Peranan Kualitatif

4. Dibawah ini, yang termasuk ke dalam fungsi kurikulum yaitu....?
a. Fungsi penyesuaian
b. Fungsi integrasi
c. Fungsi persiapan
d. Semua benar

5. suatu area umum studi yang berkenaan dengan pengembangan dan implementasi tujuan (umum dan khusus) pendidikan dan alat untuk mencapainya, yang terdiri atas teori dan praktik terintegrasi termasuk ke dalam......?
a. Bidang kurikulum
b. Praktik 

c. Persiapan
d. Studi

6. Dibawah ini yang termasuk ke dalam masalah umum kurikulum adalah...?
a. Artikulasi
b. Kontinuitas
c. Integrasi
d. Semua benar

7. Dibawah ini yang termasuk ke dalam masalah khusus kurikulum adalah..?
a. Keseimbangan
b. Sekuens
c. Artikulasi
d. Semua salah

8. Berbagai masalah yang berhubungan dengan tujuan dan hasil-hasil kurikulum yang diharapkan oleh sekolah termasuk kedalam masalah...?
a. Umum
b. Khusus
c. Semua benar
d. Semua salah

9. Contoh dari bentuk integrated curriculum...?
a. Agama
b. Bahasa
c. Perhitungan
d. Semua benar

10. Contoh dari bentuk core curriculum...?
a. Sejarah
b. Biologi
c. PPkn
d. Perhitungan

\section{ESSAY}

1. Jelaskan pengertian kurikulum? 
2. Jelaskan pengertian bidang kurikulum?

3. Sebutkan peranan kurikulum?

4. Sebutkan contoh dari bentuk integrated curriculum?

5. Apa saja contoh dari bentuk core curriculum?

\section{Kunci jawaban}

\section{PILIHAN GANDA}

1. $\mathrm{C}$

2. A

3. A

4. D

5. A

6. D

7. D

8. B

9. D

10. C

\section{ESSAY}

1. Kurikulum merupakan seperangkat rencana dan program pendidikan yang digunakan sebagai acuan oleh lembaga penyelenggara pendidikan yang disesuaikan dengan jenjang dan kebutuhan peserta didik serta dengan memperhatikan budaya lokal (Sulfemi : 3).

2. adalah suatu area umum studi yang berkenaan dengan pengembangan dan implementasi tujuan (umum dan khusus) pendidikan dan alat untuk mencapainya , yang terdiri atas teori dan praktik terintegrasi 
3. Peranan konservatif, Peranan kritis atau evaluative, Peranan kreatif

4. Agama, bahasa, Perhitungan

5. Agama, PPkn 
